\title{
La obra artística de Arcadio Blasco en Extremadura (1955-1970)
}

\author{
Artworks of Arcadio Blasco in Extremadura (1955-1970)
}

\author{
Moisés BAZÁN de HUERTA \\ Universidad de Extremadura \\ Miguel CENTELLAS SOLER \\ Universidad Politécnica de Cartagena
}

Recibido: 15-IV-2016

Aceptado: 18-VII-2016

Resumen: Arcadio Blasco (1928-2013) es un polifacético artista con una trayectoria muy consolidada en el arte contemporáneo español. Destacan en ella los murales y esculturas cerámicas, con amplia proyección pública, y sus grandes vidrieras en colaboración con diversos arquitectos. Su estilo abstracto es muy innovador y creativo.

Hasta ahora no se había estudiado su valiosa aportación en Extremadura. Intervino en bastantes iglesias promovidas por el Instituto Nacional de Colonización, renovando la plástica religiosa de la zona. Para ellas creó murales cerámicos, mosaicos, pirograbados y vidrieras. Pero también tuvo encargos de colegios e instituciones públicas. El estudio analiza dichos trabajos y permite comprobar la versatilidad de su obra y su acusada personalidad, alternando la figuración con la abstracción.

Palabras clave: Arcadio Blasco, Extremadura, Instituto Nacional de Colonización (INC), Pueblos de colonización, Arte contemporáneo, Arte religioso, Iglesias, Cerámica, Vidriera, Pirograbado.

Aвstract: Arcadio Blasco (1928-2013) was a versatile artist with a relevant and consolidated trajectory in the Spanish Contemporary Art. His most important works, with a great public projection, were ceramic murals, sculptures and big stained-glass windows in collaboration with several architects. His abstract style was very innovative and creative.

So far, its works in Extremadura had not been analysed. He worked in many churches promoted by the National Colonization Institute, renewing the religious fine art in the area. He created for these churches several ceramic murals and mosaics, stained glass and pyrography. But he was also commissioned by schools and public institutions. The paper analyses this works and it allows us to test the versatility of his work and his strong personality, which switched between figuration and abstraction.

Keywords: Arcadio Blasco, Extremadura, National Colonization Institute (INC), Colonization Villages, New Towns, Contemporary Art, Religious Art, Churches, Ceramic, Stained Glass, Pyrography. 
Tras la muerte de Arcadio Blasco en 2013, el Museu de la Universitat d'Alacant publicó un libro homenaje sobre el artista con numerosos testimonios ${ }^{1}$. Su coordinador, José Piqueras, y otros colaboradores como Rosa María Castells, coincidían en que uno de los aspectos y períodos por recuperar en su trayectoria y que más sorpresas podía depararnos era su producción de corte religioso durante los años cincuenta y sesenta ${ }^{2}$. Así es, en efecto, y este artículo supone una aportación significativa en ese sentido, centrada en una de las zonas geográficas donde la presencia de su obra es más intensa.

Para llegar hasta ese momento conviene hacer una mínima revisión de su recorrido personal y artístico ${ }^{3}$. Arcadio Blasco Pastor nació en Mutxamel (Alicante) en 1928; vivió próximo a las labores agrícolas de sus familiares, aunque su padre José era sastre y su madre María bordadora. En 1939 realiza el Bachillerato en los Maristas de Alicante. En 1942 visita durante una excursión escolar el Seminario de Orihuela y la paz y tranquilidad de aquel lugar le llevan a solicitar el ingreso. Aprende a tocar el piano y el órgano, pero se da cuenta de que su vocación no es la sacerdotal y después de tres años, en 1945, vuelve a su casa. Su padre se da cuenta que

\footnotetext{
${ }^{1}$ El presente artículo se ha elaborado en el marco del Proyecto Nacional de Investigación La patrimonialización de un territorio: conformación de paisajes culturales entre el Tajo y el Guadiana en Extremadura, HAR 201341961-P, auspiciado por el Ministerio de Economía y Competitividad.

${ }^{2}$ J. PIQUERAS MORENO, "Arcadio Blasco: el arte como oficio” y R. M. CASTELLS GONZÁLEZ, “Nuevas concepciones en el arte público de Arcadio Blasco. De la escultura al monumento", ambos en Arcadi Blasco en l'horitzó de la memòria, Alicante, 2014, pp. 66 y 96.

${ }^{3}$ Ver, aparte del libro general citado, y entre otros, M. GARCÍA VIÑO, Arcadio Blasco, Madrid, 1973; C. GONZÁlEZ BORRÁS y A. BLASCO, Arcadio Blasco. Consideraciones acerca de la cerámica en la obra de arte, Valencia, 2001; J. GARCÍA HERRERO, “Diálogos entre Arte y Arquitectura: Arcadio Blasco y Luis Cubillo", en Actas de las I Jornadas Internacionales Arte y Ciudad, Madrid, 2011, pp. 251-259; J. PIQUERAS MORENO y C. MATEO MARTÍNEZ (coords.), Arcadio Blasco. Narrador de objetos, Alicante, 2008.
}

el inquieto Arcadio no va a continuar con la profesión familiar y no le impide al año siguiente ir a Madrid.

En la capital contacta en 1947 con el pintor Luis Mosquera, que había obtenido la Primera Medalla en la Exposición Nacional de Bellas Artes de 1945 y le informa de la posibilidad de ingresar en la Escuela Superior de Bellas Artes. Visita asiduamente el Museo del Prado y malvive pintando paisajes urbanos que vende en el Rastro por 40 o 50 pesetas. En el verano regresa a su tierra y consigue una beca del Gremio de Artesanos de Alicante que le permitiría continuar los estudios.

En 1949 realiza su primera exposición individual en la sala Delclaux en Bilbao. El servicio militar le lleva a Valencia y aprovecha el traslado para terminar los estudios en la Escuela de Bellas Artes de San Carlos. Participa en un curso de Profesorado mostrando ya su interés por la Pedagogía. En 1952 consigue una beca en el monasterio de El Paular (Segovia), donde conoce a la pintora sevillana Carmen Perujo. Al año siguiente, durante una estancia en la Academia de España en Roma, contacta con los que serán posteriormente sus amigos: Manuel Hernández Mompó, Antonio Hernández Carpe, Joaquín Vaquero Turcios, José Vento, Ramón Lapayese y José Luis Sánchez, entre otros. Realiza dos exposiciones individuales en el Palacio Barberini y en los salones de la Academia y otras colectivas con sus compañeros de residencia. También establece los primeros contactos con miembros del Partido Comunista Italiano. Aunque solamente pinta, su inquietud hacia los trabajos artesanales le hace interesarse por las técnicas de los mosaicos, las vidrieras o los esmaltes; en concreto, empieza a descubrir la cerámica en el taller de Nino Carusso. Recorre en autostop el sur de Francia y toda Italia y en Milán asiste a las enseñanzas de la Escuela Montessori, donde asimila sus innovadores métodos didácticos.

En 1954 regresa a España y en su modo de entender el arte hay un cambio sustancial: 
antes le interesaban la línea y el plano, ahora la materia pictórica y se abre además a nuevas propuestas técnicas. En 1955 el arquitecto Luis Martínez Feduchi le cede, junto a José Luis Sánchez, una gran nave que los artistas acondicionan y donde trabajan junto a sus esposas y otros jóvenes creadores ${ }^{4}$. Precisamente allí conoció Arcadio al arquitecto José Luis Fernández del Amo, quien tendría un importante papel en esta iniciativa, propiciando encargos del Instituto Nacional de Colonización a Blasco y el resto del colectivo ${ }^{5}$.

También por mediación de Martínez Feduchi, el Colegio de Los Rosales le contrató como profesor de dibujo y realizó una exposición de arte infantil en la Librería Clan, pero su labor innovadora no fue entendida por unos padres retrógrados y desde la dirección del centro se le sugirió que abandonase la actividad docente, después de transmitir sus conocimientos a los niños durante tres años.

En la Sala del Prado del Ateneo de Madrid se realiza en 1957 la exposición "Tres ceramistas", con obras de Arcadio Blasco, José Luis Sánchez y Jacqueline Canivet (Fig. 1). Tuvo un gran éxito de público y ventas y fue un paso previo a la efectuada en el mismo lugar en 1959 por Arcadio denominada

\footnotetext{
${ }^{4}$ M. GARCÍA VIÑO, Op. cit., pp. 25-26. Lo comenta también José Luis Sánchez en A. TRAPIELLO, José Luis Sánchez. El rescate de los signos, Madrid, 1976, p. 181. Y el propio Arcadio en I. BLASCO, "Entrevista a mi padre. Primera etapa", en Arcadi Blasco en l'horitzó de la memoria..., pp. 208-209. Lo citamos en M. CENTELLAS SOLER y M. BAZÁN DE HUERTA, “Arquitectura y Arte en las iglesias de colonización del Valle del Tiétar", en M. M. LOZANO BARTOLOZZI y V. MÉNDEZ HERNÁN (coords. y eds.), Patrimonio cultural vinculado con el agua. Paisaje, urbanismo, arte, ingeniería y turismo, Mérida, 2014, p. 44.

${ }^{5}$ Ver M. CENTELLAS SOLER, Los pueblos de colonización de José Luis Fernández del Amo. Arte, arquitectura y urbanismo, Barcelona, 2010 y A. CORDERO AMPUERO, Fernández del Amo. Aportaciones al arte y la arquitectura contemporánea, Tesis Doctoral defendida en la Universidad Politécnica de Madrid, 2014. M. CENTELLAS SOLER, "La influencia de Fernández del Amo en el arte de las iglesias de colonización", en Pueblos de Colonización I, Córdoba, 2007, pp. 34-41.
}

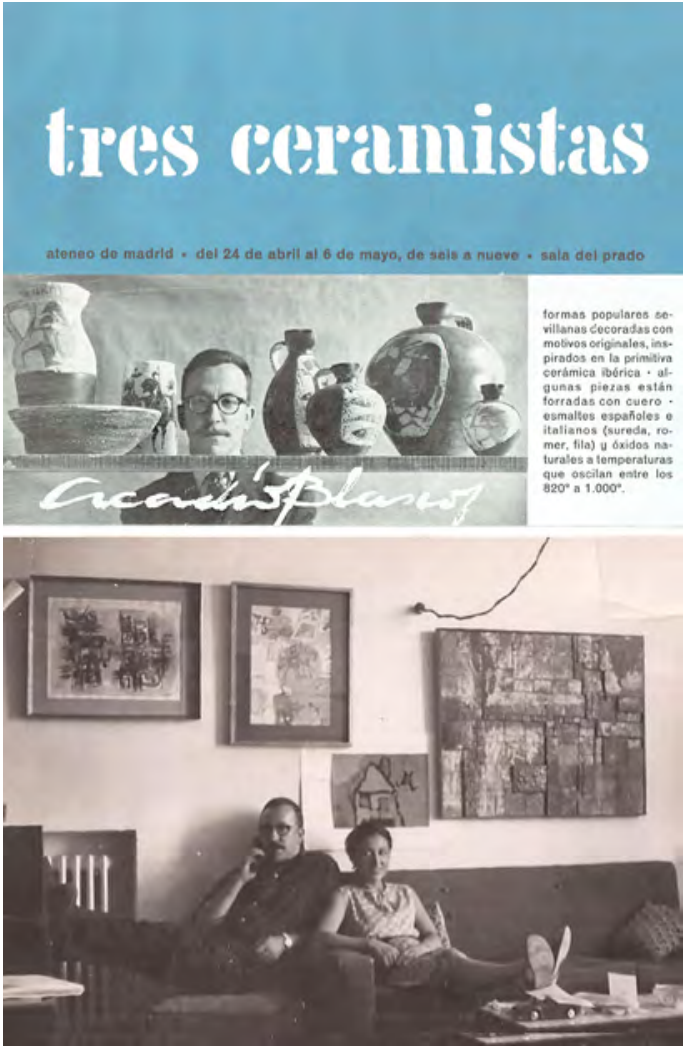

- Fig. 1. Reproducción parcial del díptico de la exposición Tres ceramistas en el Ateneo de Madrid (1957). Arcadio Blasco y Carmen Perujo en 1965. Foto cedida por Da Sara Blasco Perujo.

"Cuadros cerámicos", donde se aprecia una evolución importante del artista: ha pasado de las dos a las tres dimensiones, utiliza el grosor de las diferentes piezas de barro para dar relieve a la composición y juega con la textura de sus acabados.

En 1957 se casa con Carmen Perujo y al año siguiente nace su primera hija, Sara. Comparte el tiempo entre la investigación con la cerámica y los trabajos del INC:

"Arcadio recibe durante estos años numerosos encargos (mosaicos, vitrales, murales, bajorrelieves...) quizás alejados de la estricta reflexión pictórica personal, que le permiten, no obstante, una cierta tranquilidad económica. Pero sobre todo, le lleva a investigar con los diferentes materiales, especialmente el cerámico" ${ }^{\prime 6}$.

${ }^{6}$ J. PIQUERAS MORENO, "Arcadio Blasco en el Museo de la Universidad de Alicante", en Arcadio Blas- 
En 1959 nace su hija Argar, en el 60 Yago $y$ en el 62 Isidro, y Arcadio tiene que mantener a su familia en parte con los ingresos provenientes del Instituto Nacional de Colonización. En 1962 deben abandonar la nave prestada por Martínez Feduchi, pues van a reanudarse las obras del que sería Museo de América, inaugurado en 1965. Tras un breve paso por Ciudad Lineal, donde prepara la serie "Desarrollos", que expone en 1964 en la Dirección General de Bellas Artes, se traslada con toda su familia a Majadahonda y allí realiza la serie "Espirales". También empezó a pintar elementos cerámicos populares, ya que conocía las técnicas artesanales de los alfareros, pero supo dar su particular visión de la cerámica, como explica Carmen González Borrás?:

"Eran piezas basadas en las de su exposición de 1957, donde Blasco descubrió que podía crear un tipo de piezas de éxito comercial que aportaran más calidad que las piezas de alfarería, pero sin caer en la producción industrializada, sino que al tiempo mantuvieran el alma de la pieza artesana".

En 1967 impulsa la Asociación Sindical de Artistas Plásticos, de la que es el primer presidente electo. Su trabajo y dedicación para el INC ha llegado a su fin y tiene mucho más tiempo para dedicarse a la investigación sobre los materiales cerámicos. Su reconocimiento internacional se produce en 1970 al representar a España en la XXXV Bienal de Venecia junto a Manolo Raba y Darío Villalba. Ese mismo año participa en Valencia en la exposición "Cinco ceramistas", junto a Picasso, Miró, Artigas y Cumella. Pronto se aprecian en su obra referencias muy posicionadas ideológicamente, manifestándose en títulos con claras implicaciones políticas ${ }^{8}$, a

co, narrador de objetos..., p. 97.

${ }^{7}$ C. GONZÁLEZ BORRÁS, La obra de Arcadi Blasco (1955-1986), Alicante, 1996, p. 31.

8 "Asiento inmovilizante para torturas", "Respaldo para garrote vil"... y llamativo resulta el nombre de la exposición La cerámica de Arcadio Blasco. Muros y arquitecturas para defenderse del miedo. Restos arqueológicos, celebrada en el Palacio de Cristal de Madrid en 1984. las que habría que sumar experiencias como los Equipos de Barrio en el barrio de Portugalete de Madrid'.

Blasco consolidará un notable prestigio en las décadas siguientes, aunque no nos ocuparemos de esa etapa, mejor conocida. Dio continuidad a la pintura, mural y de caballete, y practicó también con intensidad técnicas como la vidriera. Pero será la cerámica la vía que le otorgue mayor proyección, con una importante presencia en el arte público. Exploró con ella un gran abanico de posibilidades, adaptándola al lenguaje de la modernidad y la abstracción.

Protagoniza el cuerpo principal de nuestro estudio el numeroso grupo de intervenciones de Arcadio Blasco en los pueblos construidos por el Instituto Nacional de Colonización en Extremadura entre los años cincuenta y sesenta ${ }^{10}$. El INC fue creado por el régimen franquista para intervenir en el ámbito rural español, propiciando amplias zonas de regadío que permitieran un mayor aprovechamiento agrícola. En esa operación a gran escala se erigieron unos 300 pueblos de nueva planta para asentar a los colonos que se encargarían de los cultivos. La dotación de estas localidades incluía servicios básicos, adaptados al medio, y fueron objeto de interesantes experimentos urbanísticos, al trabajar los arquitectos e ingenieros con cierto margen de libertad ${ }^{11}$.

Sobre los títulos de las obras y su trasfondo, ver R. DE LA CALLE, "Arcadio Blasco (1928-2013). Encuentros entre los objetos, las imágenes y las palabras", en Arcadi Blasco en l'horitzó de la memoria..., pp. 12-35.

${ }^{9}$ I. GARCÍA GARCÍA, “Barrios intervenidos artísticamente durante el último franquismo", Arte y Ciudad, no 3, 2013, pp. 611-640.

${ }^{10}$ Las cronologías que aportamos entre paréntesis van referidas a la fecha de redacción del proyecto del pueblo. La culminación de las iglesias con sus obras artísticas podría retrasarse hasta dos o tres años.

${ }^{11}$ Es copiosa ya la bibliografía sobre el tema. Como ejemplos significativos, ver: A. VILLANUEVA PAREDES y J. LEAL MALDONADO, La planificación del regadio en los pueblos de colonización. Historia y evolución de la colonización agraria en España. Volumen III, Madrid, 1990; M. CALZADA PÉREZ, Itinerarios de Arquitectura. 
Teniendo en cuenta los parámetros de la época, las iglesias cobraron en estos pueblos un importante papel. Los trabajos de Blasco se centran precisamente en los templos y contribuyó, junto a otros artistas, a renovar estilísticamente el panorama del arte religioso español. Es un aspecto apenas tratado en las publicaciones sobre el autor y será también objeto de revisión por nuestra parte, a nivel nacional, en el marco de la exposición que en 2017 le rendirá homenaje en Alicante bajo el título: Arcadio Blasco: arte, arquitectura y memoria.

Arcadio Blasco participó con intensidad en esta iniciativa. Realizó obras para el INC desde 1955 a 1967. En ese periodo intervino en unas 22 iglesias, de las que 10 se ubican en Extremadura (solo una de ellas en la provincia de Cáceres) y son objeto de este estudio junto a algún edificio civil ${ }^{12}$. El resto de su producción se encuentra dispersa por siete provincias, en las iglesias de Cañada de Agra (Albacete), Pueblonuevo del Bullaque y Santa Quiteria (Ciudad Real), Coto de Bornos y José Antonio-Majarromaque (Cádiz), Viar del Caudillo (Sevilla) ${ }^{13}$, La Montiela, Maruanas y Mesas de Guadalora (Córdoba), Puebloblanco (Almería) y Fuente Caldera

Pueblos de colonización I, II, III, Córdoba, 2006-2008; VV. AA., Pueblos de colonización durante el franquismo: la arquitectura en la modernización del territorio rural, Sevilla, 2008; VV. AA., Pueblos de colonización en Extremadura, Mérida, 2010; J. A. FLORES SOTO, Aprendiendo de una arquitectura anónima. Influencias y relaciones en la arquitectura española contemporánea: el INC en Extremadura, Madrid, 2013; E. DELGADO ORUSCO, Imagen y memoria. Fondos del archivo fotográfico del Instituto Nacional de Colonización 1939-1973, Madrid, 2013.

${ }^{12}$ Para valorar otras referencias religiosas del INC en la provincia de Cáceres, ver M. BAZÁN DE HUERTA y M. CENTELLAS SOLER, "Arte religioso en los pueblos de colonización del Valle del Alagón" y M. CENTELLAS SOLER, M. BAZÁN DE HUERTA y A. E. ABUJETA MARTÍN, “Las iglesias en los pueblos de colonización del Valle del Alagón. De la planta basilical a la posconciliar", ambos en M. M. LOZANO BARTOLOZZI y V. MÉNDEZ HERNÁN (coords. y eds.), Paisajes modelados por el agua. Entre el arte y la ingeniería, Mérida, 2012, pp. 393-421 y 275-294.

${ }^{13}$ En este caso el mural no se conserva. y El Chaparral (Granada). Precisamente en esta última Blasco aborda ya un proyecto global, al ser el autor de las vidrieras del presbiterio y naves laterales, el altar y el mural cerámico de la fachada, circunstancia similar a los pueblos extremeños de Tiétar, Los Guadalperales y Puebla de Alcollarín, donde asume casi todas las manifestaciones artísticas, como pronto veremos.

Las técnicas por tanto son muy variadas y alguna tan original como el pirograbado solo aparece en los pueblos de la comunidad autónoma extremeña, lo cual singulariza esta zona. En las vidrieras alcanza resultados realmente notables, tanto en las realizadas en hormigón como en las emplomadas. Explicaba Arcadio que las transportaba en un Land Rover con remolque, las montaban durante varios días y dormían en cualquier fonda próxima a la iglesia en la que estaban colocando los vitrales ${ }^{14}$.

Al plantearnos la organización y presentación del estudio barajamos dos opciones. Una podía ser comentar sus intervenciones en cada una de las iglesias, ventajosa para aquellos templos en que su trabajo se puede considerar global; pero el esquema podría resultar reiterativo al tener que volver una y otra vez sobre las diferentes técnicas. De ahí que hayamos optado por una presentación alternativa, en la que articulamos los principales campos, analizando en cada uno sus características y las peculiaridades estilísticas e iconográficas que aportan las distintas iglesias.

Los trabajos del INC recogen dos tipos de situaciones. Algunos son encargos con una mayor implicación personal y se elaboran in situ, pero en otros casos el artista realiza el diseño sin visitar previamente el enclave. Lo habitual es un contacto con el arquitecto o promotor y pactar los temas, espacios y dimensiones. Hay referencias en este

\footnotetext{
${ }^{14}$ Comentario de Arcadio Blasco en una reunión mantenida con Miguel Centellas en su casa de Bonalba el 31 de enero de 2009.
} 
sentido $^{15}$. Cabe suponer por tanto una estrecha comunión entre arquitecto y artista. El primero determina el lugar de las vidrieras y la escala adecuada para las obras que van en el presbiterio, el coro o las naves. Blasco tendría por tanto que adaptarse a estos condicionantes, pero es probable que contara con bastante libertad al resolver los contenidos.

La identificación de las obras es un proceso complejo. En los archivos con fondos del INC son muy escasas las noticias sobre la autoría de las artes plásticas en las iglesias ${ }^{16}$. Hemos localizado algunas fichas con atribuciones, que en parte nos sirven de guía, aunque no siempre son completas ni fiables. Nos ha ayudado una selección de fotografías que conservaba Arcadio Blasco, producto de un viaje que hizo por Extremadura para visitar alguno de los enclaves y que facilitó a Miguel Centellas. También nos resulta útil que el autor tenga algunas líneas estilísticas bastante definidas, pues contribuyen a identificar sus imágenes cuando no hay refrendo documental. Con ello hemos podido ir completando un complejo mosaico y ofrecer estos datos de autoría es una de las aportaciones de nuestro artículo ${ }^{17}$.

${ }^{15}$ M. BAZÁN DE HUERTA, "Rivera antes de Rivera. Los trabajos pictóricos de Manuel Rivera para el Instituto Nacional de Colonización", Arte y Ciudad, no 9, 2016, pp. 61-90.

${ }^{16}$ Los principales son los del Ministerio de Agricultura, Alimentación y Medio Ambiente, en sus sedes del propio Ministerio y en San Fernando de Henares, más el archivo del Centro de Estudios Agrarios de la Junta de Extremadura en Mérida.

${ }^{17}$ Una ficha del INC atribuye a Blasco y su esposa Carmen Perujo la escultura de gran formato de San Fulgencio en el altar de la iglesia de Los Guadalperales. Entrevistada Carmen Perujo en 2016 por José Piqueras, la reconoce como suya, sin intervención de Arcadio. Por otra parte, las vidrieras de la iglesia de Pizarro se atribuyen a Blasco en una ficha del INC, y junto a su segunda pareja, Carmen Naranjo, Blasco las fotografió a finales de los ochenta en su viaje por Extremadura. Cabría por tanto adjudicarle su autoría, pero mantenemos dudas estilísticas y pensamos que, aunque Arcadio Blasco pudiera concebir su diseño, la ejecución cabría asignarla a Ángel Atienza, por ello hemos optado finalmente por no incluirlas.
Con esta información y tras un intenso trabajo de campo ${ }^{18}$, pasamos ya a evaluar las distintas manifestaciones artísticas, detectando la ausencia de pinturas sobre lienzo o tabla, una práctica que sí aparece en otras iglesias del INC. Dos formas de arte destacan: la cerámica y la vidriera, aunque no olvidemos el uso del mosaico y la introducción de técnicas tan inusuales como el pirograbado.

Son numerosos los trabajos cerámicos de Arcadio Blasco y se sitúan tanto en exteriores como interiores. Antes de comentar los más significativos, presentamos una actuación modesta, pero que podría constituir casi un apartado propio. Nos referimos a cuatro relieves cerámicos, con los símbolos de los evangelistas, situados en el presbiterio de la iglesia de Tiétar (Cáceres). El Tetramorfos, que encarna, alados, al toro (San Lucas), el águila (San Juan), el león (San Marcos) y el ángel (San Mateo), se muestra en piezas modeladas en un solo bloque, con volumen resaltado y cierta desproporción que se ajusta al formato elegido. Estos elementos iconográficos se disponen apaisados bajo las imágenes personificadas de sus homólogos en tablas verticales pirograbadas que comentaremos más adelante.

Es la obra que más se acerca al proceso escultórico. De hecho es la única en realidad, pues el resto de ejemplos utiliza la cerámica plana, seccionada en piezas sobre las que se aplica el trazo con barnices, y por tanto con unos resultados más próximos a la pintura.

La propia iglesia de Tiétar (1957) presenta en el exterior un primer panel cerámico con un ángel que ostenta en una filacteria el cántico Alleluia. Muestra un trazo lineal con pinceladas rápidas de relleno. Su fondo uniforme y triangulado recuerda a la portada de Puebla de Alcollarín, algo posterior, y ofrece también paralelismos con otros ángeles dispuestos por Blasco en torno a esos

\footnotetext{
${ }^{18}$ Agradecemos a Esther Abujeta Martín su colaboración en este sentido.
} 


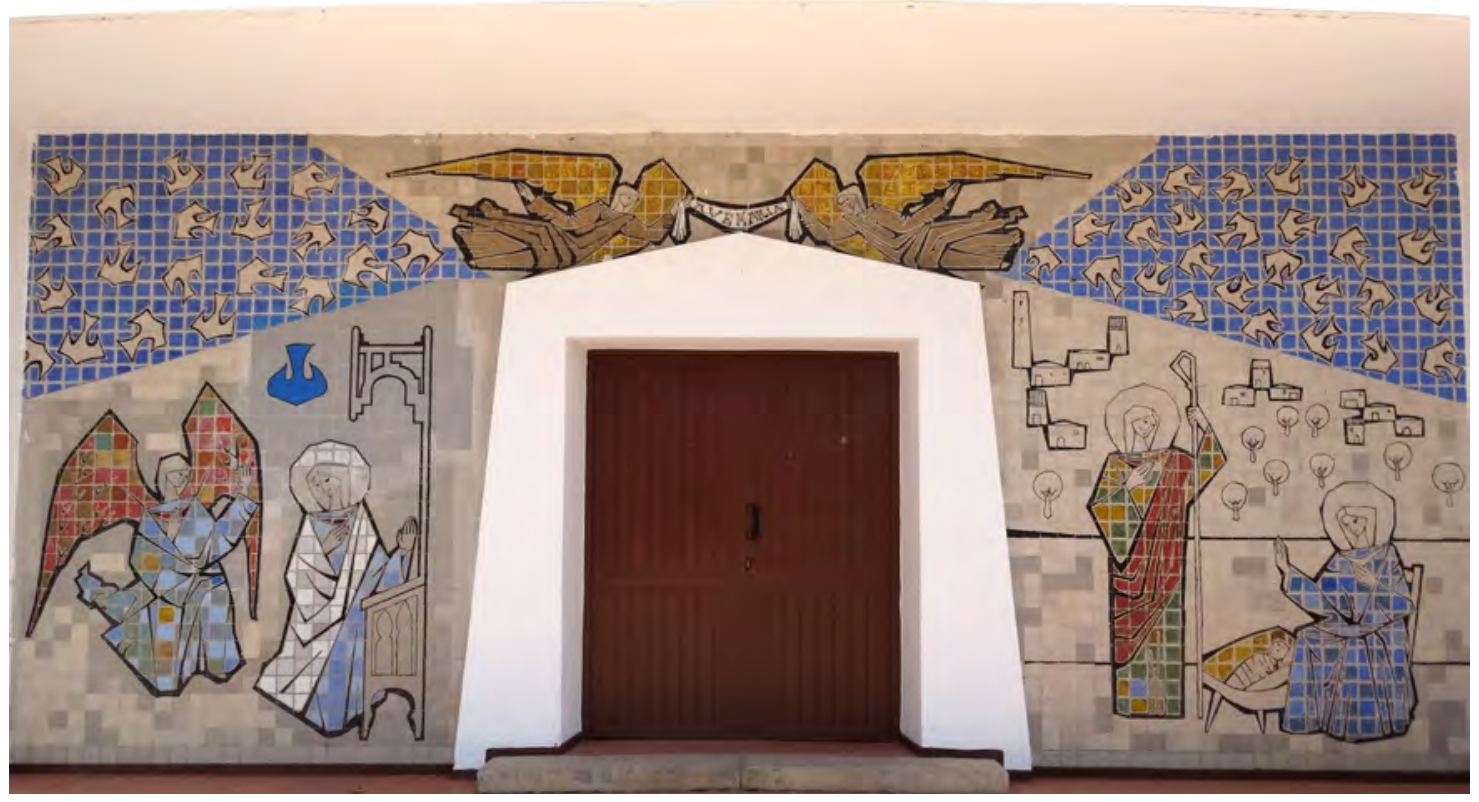

- Fig. 2. Arcadio Blasco. Mural cerámico en la fachada de la iglesia. Los Guadalperales. Foto de los autores.

años en Los Guadalperales y Santa Quiteria (Ciudad Real).

Más relevante por su entidad es el gran mural situado en el pórtico de acceso ${ }^{19}$. Representa el episodio de Pentecostés, con la aparición de las lenguas de fuego sobre la Virgen María y los Apóstoles, dando pie a su labor predicadora. Los personajes rodean, de pie y arrodillados, a la Virgen entronizada en la zona central. La disposición del rostro femenino es la única diferente, ya que el apostolado acusa una marcada isocefalia. Los trazos son sintéticos, delimitando amplios planos con los pliegues de las túnicas, resueltas con una gama de color armónica. Este efecto, próximo al de las vidrieras, establece un interesante paralelismo estilístico con otras obras de la propia iglesia y ejemplos como Pueblonuevo del Bullaque (Ciudad Real, 1956).

Aún habría que citar la realización del Via Crucis, elemento consustancial a todas las iglesias de colonización. Lo excepcional en la zona es que se concibe como una representación anicónica. Una o dos cruces acom-

\footnotetext{
${ }^{19}$ Para la iglesia de Tiétar seguimos en parte nuestros comentarios previos en M. CENTELLAS SOLER y M. BAZÁN DE HUERTA, “Arquitectura y Arte...”, pp. 37-64.
}

pañan los textos de cada una de las catorce estaciones. Pero el último párroco decidió taparlos y sustituirlos por imágenes figurativas, dejando sólo una pieza como testimonio. Sí se conserva un Via Crucis igual en la iglesia de Puebloblanco (Almería).

Otro conjunto muy interesante es el que presenta la portada de la iglesia de Los Guadalperales (1956) (Fig. 2). Está dividido en dos secuencias, a un lado y otro de la puerta y enlazadas por sendos ángeles adaptados al marco en la parte superior. Cobija las escenas un cielo azul con una copiosa bandada de pájaros, cuyo cariz es propio del autor.

En la Anunciación del Ángel a María los protagonistas se disponen arrodillados bajo la presencia del Espíritu Santo, girándose la Virgen con elegancia y rostro afable. La zona opuesta muestra el nacimiento de Jesús. La Sagrada Familia se adelanta a un fondo donde árboles y pequeñas casas parecen flotar en el espacio y bien podrían sintetizar uno de estos pueblos de colonización, adaptando oportunamente el tema ${ }^{20}$.

\footnotetext{
${ }^{20} \mathrm{El}$ mismo tipo de casas y una iglesia con su torre reaparecen en 1957 en el Bautismo de Cristo de la iglesia de Santa Quiteria (Ciudad Real).
} 
La composición global, articulada por diagonales, es dinámica y atractiva. El trazo es preferentemente lineal, con textura en la aplicación. Las figuras contienen fragmentos vidriados con distintas gamas de color y ricos matices. El deterioro y desprendimiento de algunas piezas hizo precisa una restauración que fue abordada a fines de los años noventa. Asumió el reto un artista local, incorporando nuevos azulejos tratados con pintura. Es una labor digna, que equilibra la integración global de la imagen con la distinción suficiente para que se aprecie la zona intervenida, sobre la cabeza de la Virgen María.

La iglesia de Zurbarán (1957) (Fig. 3) ofrece por parte de Arcadio Blasco una solución original que se ubica en el exterior. La portada se retranquea para crear un pórtico abierto previo al acceso. En sus dos muros laterales se sitúan sendos paneles de terracota, cocidos en piezas rectangulares que no se adaptan en sus márgenes a un marco concreto. Esta disposición anima los murales, que se recortan de forma irregular y dinámica ante el fondo blanco de la pared. La cocción de los segmentos se realiza sin vidriado, por lo que el color terroso y opaco es uniforme. Arcadio Blasco utiliza un marrón más oscuro para los trazos de las figuras y el negro para las letras. Encaja esta línea con el proceso estilístico y técnico que caracterizará la mayor parte de su producción fuera del marco del INC.
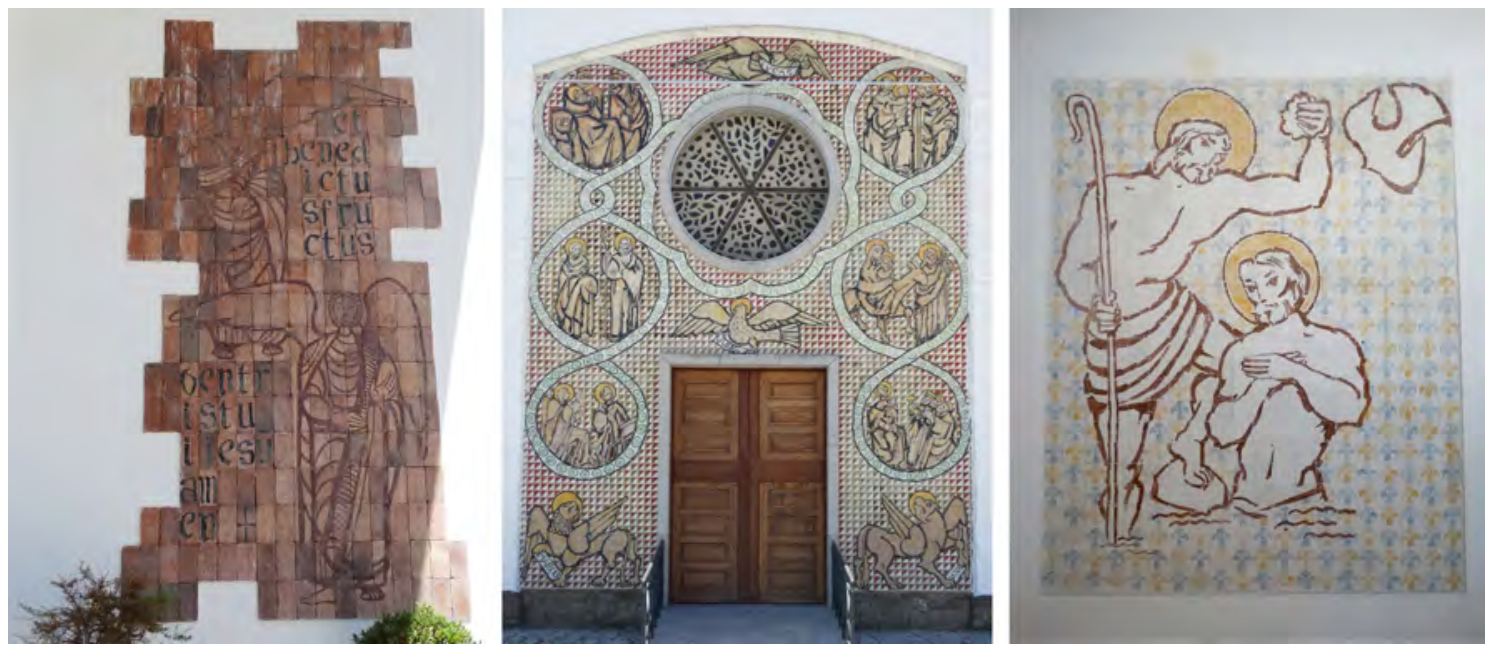

- Fig. 3. Arcadio Blasco. Murales cerámicos en Zurbarán y Puebla de Alcollarín. Fotos de los autores. 

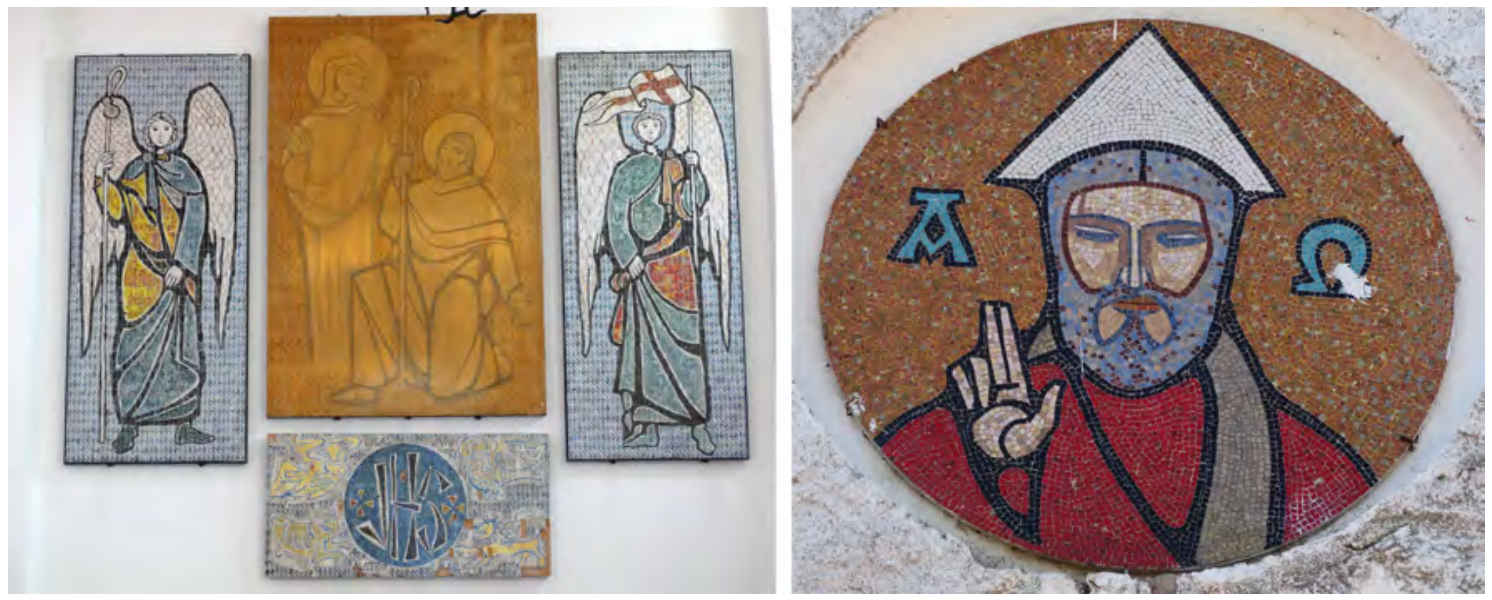

- Fig. 4. Arcadio Blasco. Presbiterio de La Bazana y mosaico en Brovales. Fotos de los autores.

gonal que alterna los colores blanco y rojo, aunque se perciben también irisaciones verdes. Esta trama regular otorga uniformidad al conjunto. A ella se superpone el elemento más llamativo: tres cintas ornamentadas con pequeños círculos verdes que se entrelazan y ocupan sinuosamente el espacio. Sirven para organizar la composición, pues configuran los círculos en los que se sitúan las distintas escenas.

Iconográficamente encontramos los símbolos de los cuatro evangelistas, distribuidos de forma un tanto aleatoria, con el león y el toro simétricos en la zona inferior y el águila y el ángel sobre la puerta y el rosetón. Se identifican con filacterias, pero una apresurada resolución llevó al artista a intercambiar los nombres de Lucas y Mateo. Blasco dispone los episodios evangélicos bajando desde la zona superior izquierda $\mathrm{y}$ ascendiendo a la inversa. Muestran, consecutivamente: el nacimiento de la Virgen María, los Desposorios, la Anunciación, la Adoración de los Magos, la Huida a Egipto y como remate la Sagrada Familia.

Se resuelven con gruesas líneas negras, que siluetean las figuras sin demasiada precisión, al igual que en los rostros, bastante abocetados. También los trazos internos parecen aplicados con rapidez y escaso cuidado, algo no habitual en la trayectoria del autor y por ello sospechamos que pudo verse apremiado por los plazos.
Sin embargo, resulta interesante otro mural ubicado en el interior. Es la escena del bautismo de Cristo por San Juan, situada en el baptisterio. Es el único ejemplo cerámico del artista con este tema en tierras extremeñas. Aquí el fondo alterna pétalos de flores azules y amarillos dispuestos de forma regular y pulcra. El trazo que siluetea las dos figuras es discontinuo, pero en este caso cobra personalidad. Parece un apunte de factura dinámica y deja en blanco el interior con una grata sensación de limpieza. Su factura es casi idéntica al posterior (1965) mural cerámico de Mesas de Guadalora (Córdoba), aunque en el andaluz impera el color azul y el fondo alterna veneras con la paloma del Espíritu Santo.

En el presbiterio de La Bazana, la iglesia más temprana del conjunto (1955), dos ángeles simétricos, de elaborada ejecución, flanquean el panel central en madera con la aparición de la Virgen María a Santiago el Mayor y que se citará en otro bloque (Fig. 4). Son imágenes gemelas, frontales, con efecto de vidriera en su distribución interna, marcada por gruesas líneas negras. El primero porta un bordón de peregrino con la calabaza colgando, y su compañero una bandera cristiana con cruz roja sobre campo blanco, vinculada también con el culto jacobeo; en ambos la otra mano sujeta la túnica generando pliegues curvos. Manchas informales rellenan las zonas de la túnica, mientras las alas señalan el plumaje con trazos más finos. 
El fondo geométrico, muy regular, sigue el motivo romboidal del panel en madera que centra el altar.

El conjunto de La Bazana se completa con un panel horizontal de pequeñas piezas cerámicas rectangulares sobre un soporte de madera. Una fotografía antigua revela que estuvo situado como frente en la mesa de al$\operatorname{tar}^{21}$, y cabe suponer que fue concebido así por la coincidencia en las medidas. En fecha imprecisa fue trasladado al muro del presbiterio, bajo el panel pirograbado. Consta de un círculo azul central con el anagrama JHS, pintado con trazos angulosos muy personales. A su alrededor y en amarillo los cuatro símbolos del tetramorfos, identificados también por los nombres de los Evangelistas y donde de nuevo vemos cambiados los nombres de Lucas y Mateo. Y es que todo apunta a que, como en la fachada de Puebla de Alcollarín, pudo haberse realizado con cierta prisa. El trazo es abocetado, la trama geométrica del fondo irregular y sus manchas no siguen un patrón uniforme, disponiéndose más bien para rellenar huecos. El desprendimiento de piezas mal adheridas acentúa su carácter precario, y serán difíciles de recuperar.

Los tres paneles anteriores están constituidos por pequeñas piezas de $5 \times 2,5 \mathrm{~cm}$, por lo que producen un cierto efecto de mosaico. Con todo, son fragmentos regulares y que no generan color, sino que éste se aplica sobre ellos. El tema nos permite enlazar con un nuevo campo plástico, porque también Extremadura cuenta con un mosaico de Arcadio Blasco (Fig. 4). Se sitúa en el exterior de la fachada de la iglesia de Brovales y es un tondo realizado con la técnica clásica del opus tessellatum. Las piezas son de pequeño tamaño y con ello gana en calidad, pero resulta casi innecesario dada la distancia a la que está colocado del suelo. Aun así, el diseño mantiene cierta tendencia sintética, enmarcando el rostro en amplios planos y unificando el pelo y la barba en una sorpren-

\footnotetext{
${ }^{21}$ Conservada en el Centro de Estudios Agrarios de
} Mérida. dente gama azul. Cabe objetar la pequeña escala de la mano, pero no resta entidad a esta atrevida imagen de Dios Padre bendiciendo, con el triángulo equilátero de la Trinidad sobre la cabeza y entre las letras Alfa y Omega, como principio y fin, primero y último ${ }^{22}$. Esta técnica no es muy habitual en el artista, pero encontramos ejemplos interesantes en el bautismo de Cristo en la iglesia de Pueblonuevo del Bullaque y en la parroquia de la Inmaculada Concepción en Elda, además del exterior de la iglesia de José Antonio-Majarromaque (Cádiz).

El pirograbado es una de las técnicas que singulariza la aportación de Arcadio Blasco, pues es el único autor que la utiliza en las iglesias de colonización extremeñas (Fig. 5). Tampoco a nivel nacional es un medio frecuente. Conocemos algunas obras de Antonio Suárez, en concreto la capilla del Hospital General de Asturias, con un sencillo trazo lineal, y la iglesia de La Corredoria de Oviedo, donde la zona quemada es el fondo y no las figuras ${ }^{23}$; algún ejemplo disperso hay también en la zona de Aragón. Pero Blasco utiliza esta técnica con más frecuencia y le otorga señas de identidad.

El soporte son paneles de madera o contrachapado, y el procedimiento consiste en dibujar sobre el material con un punzón caliente, regulado por un transformador y con un juego de puntas metálicas que permite distintos acabados. De este modo, las líneas principales, que siluetean los personajes y las subdivisiones interiores, adquieren un mayor protagonismo, por su anchura y profundidad, al aplicarles sucesivos pases. Las zonas internas de las túnicas suelen dejarse con el color y la veta natural de la madera, que también juega su papel. Pero el punzón a la vez permite efectos decorativos, que suelen aplicarse en los fondos.

Llamativo es precisamente el fondo ornamental de los paneles en la iglesia de Tié-

\footnotetext{
${ }^{22}$ Apocalipsis 22, 13.

${ }^{23}$ A. GAGO, El arte de Antonio Suárez aplicado a la arquitectura, Gijón, 2009, pp. 104, 127 y 128.
} 


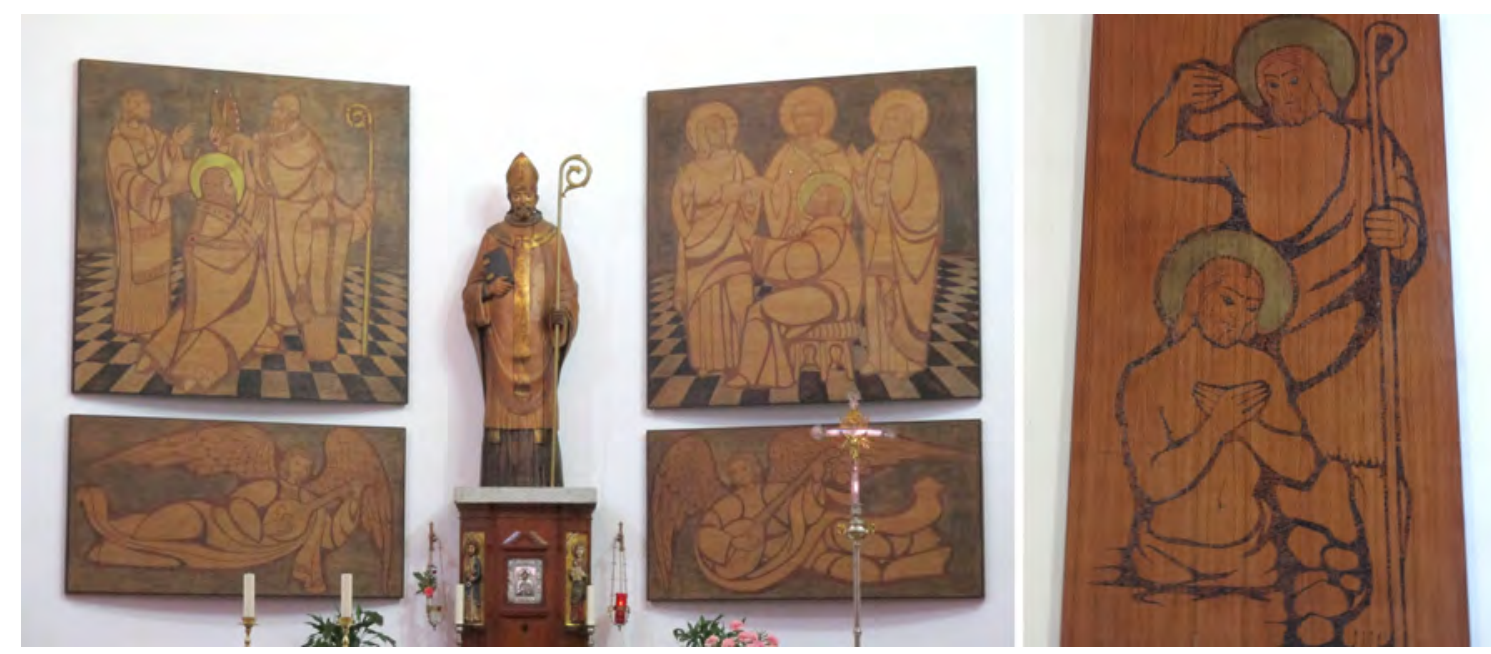

- Fig. 5. Arcadio Blasco. Paneles pirograbados en Los Guadalperales y Puebla de Alcollarín. Fotos de los autores.

tar, alternando motivos animales y geométricos, y donde no se han ocultado algunos pentimenti y apuntes previos a lápiz. La segmentación de las túnicas con profundos pliegues sigue una estética similar a los apóstoles cerámicos de la entrada, aunque ahora sí se personalizan los rostros. Notas singulares son también la disposición frontal, el sombreado de los nimbos y los signos ininteligibles (parecidos en algún caso a la escritura china) en la filacteria de San Mateo, confiando, intuimos, en que por su distancia no serían percibidos.

Una factura especialmente cuidada presentan los paneles del presbiterio de la iglesia de San Fulgencio en Los Guadalperales (Badajoz). Entrevistado Arcadio Blasco en 2009 por Miguel Centellas en su casa de Bonalba (Mutxamel, Alicante), el artista indicó que las tablas fueron realizadas con su esposa, la pintora, escultora y ceramista Carmen Perujo. Pero ésta, en diálogo con José Piqueras en 2016, señala que los pirograbados "son cien por cien de Arcadio". Datos contradictorios, por tanto, que dejan abierto el tema, aunque estilísticamente el estilo de Arcadio en estas obras resulte inconfundible.

Dos paneles superiores representan la iconografía de San Fulgencio, estrechamente vinculado con Extremadura. El primero, de compleja distribución, muestra al santo arrodillado, ataviado con la casulla, en el acto de recibir el báculo y la tiara de obispo de Écija y Cartagena. El segundo, más relevante por su iconografía, reúne al santo sedente junto a sus tres hermanos: San Leandro, San Isidoro y Santa Florentina. Todos están identificados en sus nimbos, y parecen dialogar sobre las sagradas escrituras, al ser dos de ellos doctores de la iglesia. Notas singulares de ambas obras son la diferenciación del nimbo dorado del protagonista; el ajedrezado del suelo, con un punto de fuga muy acentuado y fortalecido en negro para destacarlo del tono marrón de la madera; y por último la inserción de pequeños apliques vítreos sobre la casulla, la tiara y los anillos, aportando una práctica singular que remite a fórmulas medievales y no tiene parangón en otros trabajos del artista.

Bajo ellos, dos ángeles músicos vuelan en disposición apaisada tocando sendos laúdes o instrumentos de cuerda. Su atuendo genera elegantes curvas gruesas en los pliegues, que aquí contrastan con el trazo finísimo, delicado y más realista que aplica al rostro, manos y alas.

En el Sur de Badajoz, la iglesia de La Bazana combina en el presbiterio un tablero central en madera con los cerámicos ya descritos, lo cual permite establecer analogías y diferencias en estilo y técnica. En ambos dispone como fondo una trama regular a partir de rectángulos, rombos y diagonales, que en el panel de madera sólo se interrumpe 


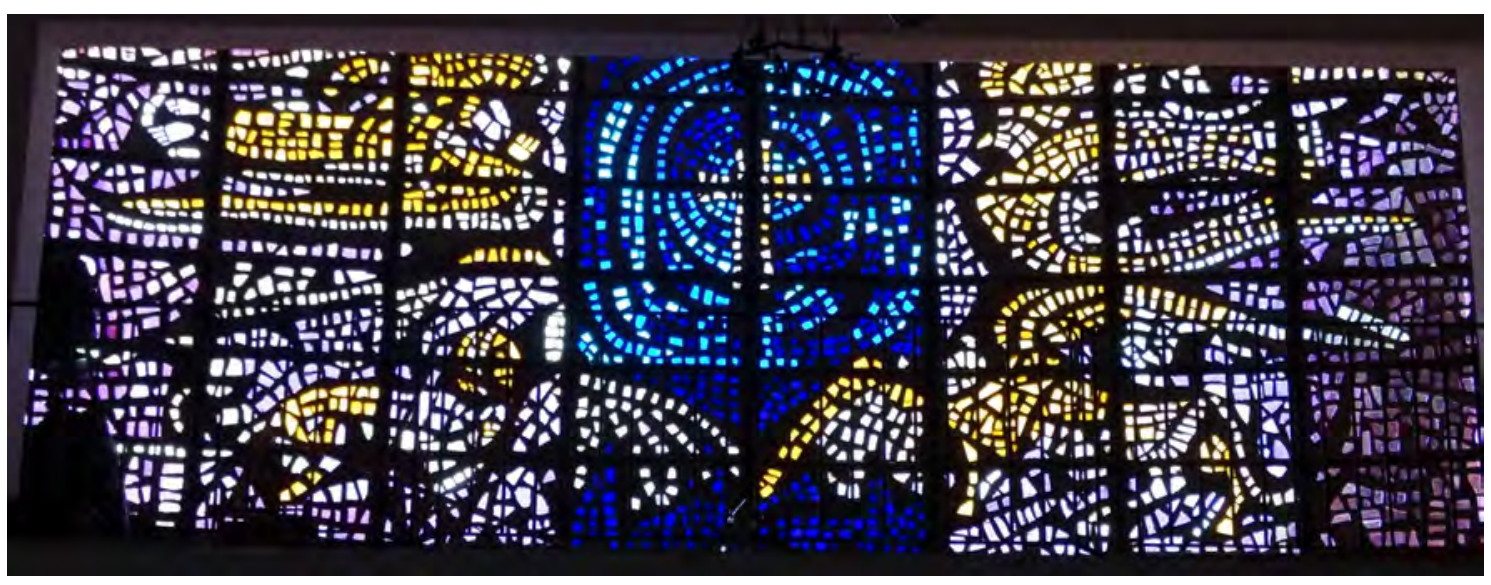

- Fig. 6. Arcadio Blasco. Vidriera del coro de la iglesia de Los Guadalperales. Foto de los autores.

en la zona superior con unos sutiles ángeles que equilibran la presencia arrodillada del apóstol Santiago ante la Virgen María. Éste porta un bordón, y su postura genera un interesante juego de pliegues curvilíneos que siguen la fórmula habitual en el artista. Blasco mantiene su natural elegancia a pesar de lo forzado de la actitud. Con todo, este panel presenta peculiaridades técnicas. El paso del tiempo ha generado algunos desprendimientos y permite descubrir la incorporación de un material plástico transparente sobre la tabla, aplicándose el trazado lineal directamente en el primero.

Riguroso con la técnica es el último ejemplo, situado en Puebla de Alcollarín. Su programa iconográfico se centra en la figura del Bautista y se ubica en dos zonas. En el presbiterio destacan en paneles verticales las escenas de la Visitación de la Virgen María a su pariente Santa Isabel, madre de San Juan; y en paralelo el bautismo de Jesús. Su trazo es claro y rotundo, con las transiciones curvas propias del autor y la peculiaridad del verde en las aureolas. Sorprende la introducción de un nuevo soporte: la reja y la puerta que marcan el acceso a la nave, en la que se insertan sendos paneles con San Juan en pie y un elegante ángel. Nuestra investigación ha facilitado el hallazgo y colocación de la tabla que cerraba la parte superior con una nueva leyenda, paralela a las dos ya situadas tras el altar ${ }^{24}$.

${ }^{24}$ Los textos rezan: "Desde el seno de mi madre me llamó Dios por mi nombre"; "Hubo un hombre enviado
Hemos dejado para el final el extenso apartado de las vidrieras, uno de los más valiosos por su carácter innovador. Están presentes en un gran número de templos (ubicados sobre todo en las Vegas Altas del Guadiana) y desarrollan programas muy amplios, por lo que habremos de ser más sintéticos en su descripción. Reflejan cierta alternancia de estilos, lo que incrementa su interés. Blasco solventa con inteligencia las limitaciones expresivas del medio, innovando en los temas e introduciendo elementos simbólicos y también la abstracción, un salto cualitativo importante. Utiliza técnicamente tanto el cemento como el plomo a la hora de engarzar las dallas e incluso encontramos aplicaciones de óleo sobre el vidrio. Los formatos son variados y se adaptan al marco, pues se ubican en presbiterios, naves, coros y capillas bautismales. Cabe señalar que algunas iglesias se han protegido por medio de cristales transparentes (Brovales) o mallas metálicas (Palazuelo, Obando, Puebla de Alcollarín), para evitar roturas desde el exterior.

Entre los vitrales fragmentados con engarce de hormigón destaca la espectacular vidriera que ilumina el coro de la iglesia de Los Guadalperales (Fig. 6). Ocupa una amplia superficie horizontal, en tonos fríos. Una cruz blanca centra la escena entre cír-

de Dios llamado Juan el Bautista”; y la encontrada: “Tú serás llamado profeta del Altísimo porque irás delante del Señor a preparar sus caminos". 

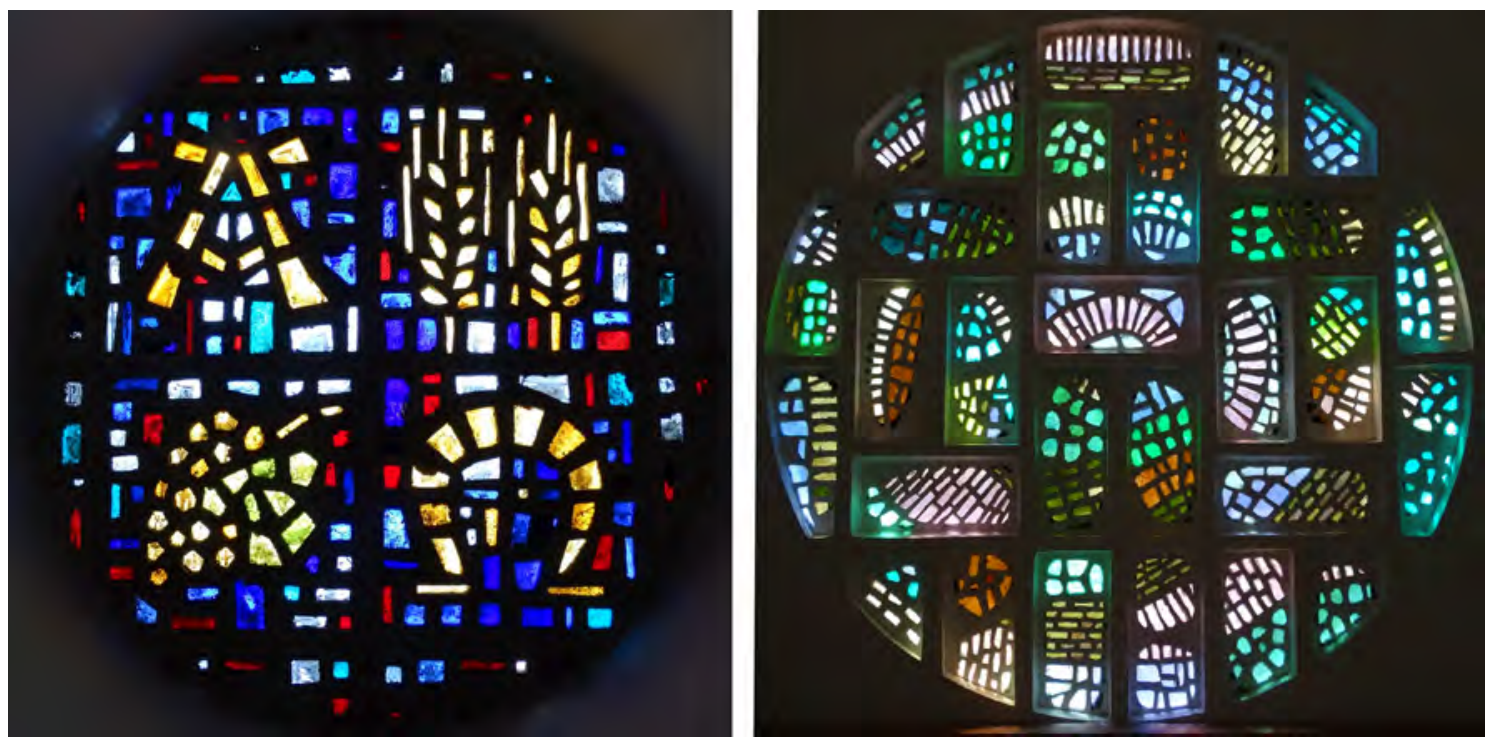

- Fig. 7. Arcadio Blasco. Rosetones de las iglesias de Zurbarán y Hernán Cortés. Fotos de los autores.

culos concéntricos irregulares de un intenso azul. Los cuatro símbolos del Tetramorfos, con disposición apaisada, ocupan el resto del espacio, en colores blanco y amarillo, con los extremos violáceos. El león y el toro despliegan grandes alas, a juego con el ángel y el águila. Cada pieza mantiene los números indicativos para facilitar su montaje, configurado por 48 rectángulos, adaptándose a la curvatura superior.

También ofrecen un aspecto muy atomizado las vidrieras de la nave, dispuestas en ventanales dobles unidos por hormigón. No son muy grandes, pero sí numerosas (cinco a cada lado) y luminosas por su claridad. Representan aves en vuelo y espigas, en formas muy sintéticas, no siempre fáciles de identificar.

Uno de los trabajos más interesantes es la iluminación del templo de Zurbarán. Y se debe al hecho de apostar ya por la abstracción en su diseño. En la mayoría de las iglesias, aunque en algunas sea difícil de percibir, siempre encontramos alusiones más o menos reconocibles. Sin embargo, las doce vidrieras rectangulares que iluminan el presbiterio, y las otras veinte distribuidas de dos en dos en las naves y el coro, no incorporan ningún elemento figurativo, pretenden crear un universo estético y espiritual.
Arcadio Blasco revela un buen conocimiento del Neoplasticismo de Piet Mondrian, que reinterpreta con dallas blancas y de colores primarios distribuidas en medido equilibrio. El cemento asume el papel de las líneas negras, aunque con menos rigor geométrico que en la pintura del holandés. Su grosor ayuda a que los colores primarios destaquen con intensidad cuando la luz los atraviesa.

Su valor reside además en que un movimiento artístico desconocido para gran parte de la población, se incorpore con naturalidad a su lugar habitual de encuentro: la iglesia. Penetra así la vanguardia no sólo en ámbitos rurales, sino en un medio como el religioso, tradicionalmente muy conservador.

El conjunto se completa con el rosetón que ilumina el coro, que utiliza el mismo sistema fragmentario, pero sí representa un programa iconográfico. Las letras Alfa y Omega y las alusiones eucarísticas al pan y el vino, con espigas de trigo y un racimo de uvas, ocupan el espacio circular entre una amplia gama de colores. En cualquier caso, el azul es el dominante, como en toda la nave, y refuerza el sentido espiritual perseguido.

Hemos dispuesto en paralelo la imagen del rosetón de la iglesia de Hernán Cortés (1962) con la de Zurbarán, pues supone una interesante alternativa (Fig. 7). Aquí Arcadio 



- Fig. 8. Arcadio Blasco. Vidrieras de la iglesia de Palazuelo. Fotos de los autores.

apuesta de nuevo por la abstracción, con un singular montaje: sus piezas son rectángulos, pero con motivos internos que generan una sensación concéntrica o rotatoria; en los colores impera el verde y adquiere por ello cierta evocación vegetal. El mismo color y esquema, aunque menos compartimentado, se repite en los dos grandes óculos que iluminan la parte superior del presbiterio.

En la nave, las vidrieras rectangulares en vertical se enmarcan por dos franjas, de nuevo verdes, con sucintas cruces de largos brazos horizontales. Los motivos que albergan los cuadros resultantes se repiten a uno y otro lado, aunque dispuestos de forma alterna. Representan así una espiga de trigo, una hostia consagrada, un sol radiante, una paloma y un candil encendido.

Un último espacio con sendas capillas, en el lado del Evangelio, alberga cuatro nuevos vitrales cuadrados. Son muy coloristas, aunque no consiguen iluminar con intensidad los recintos, oscuros por sus bajos techos y el añadido de una celosía de separación con la nave. Los motivos aquí son un ojocorona, un sol, una flor y un corazón atravesado por una espada.

Algunos de los temas citados se encuentran también en la iglesia de Palazuelo (1961), uno de los pocos casos, con Hernán Cortés, Obando y El Torviscal, en que la intervención de Arcadio se reduce a las vidrieras (Fig. 8). El repertorio se completa ahora con plantas, estrellas, insectos, copones, las siete velas del candelabro judío, el cordero pascual y algún otro elemento de compleja identificación. Ello se debe al carácter fragmentado de las imágenes y en parte al uso del cemento como enlace. El grosor de las líneas en relación al espacio disponible dificulta a veces distinguir entre fondo y figura o precisar el tema.

Los formatos en Palazuelo son apaisados en las naves altas, alternando gamas cálidas y frías. Cambian a cuadradas en las dos plantas que subdividen el lado del Evangelio, ya que integra también en el lateral el amplísimo coro. A los pies de éste se dispone como es habitual un gran rosetón, con la paloma del Espíritu Santo. Y aún hay que sumar la capilla bautismal, donde destaca una vidriera especialmente afortunada por la riqueza de sus tramas y colores primarios.

El grupo de iglesias cuya factura mantiene cierta identidad abarca también a Puebla de Alcollarín (Fig. 9). Son cinco vitrales
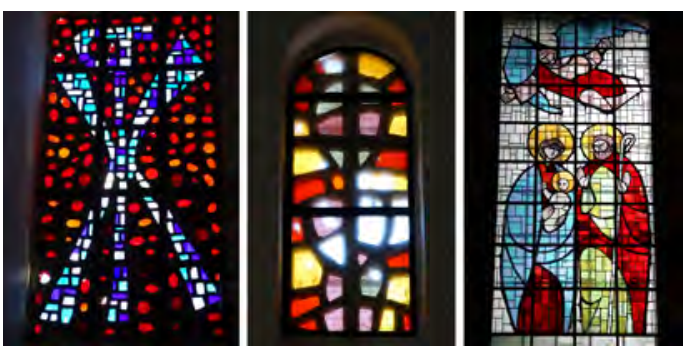

- Fig. 9. Arcadio Blasco. Vidrieras de Puebla de Alcollarín, Obando y Tiétar. Fotos de los autores. 

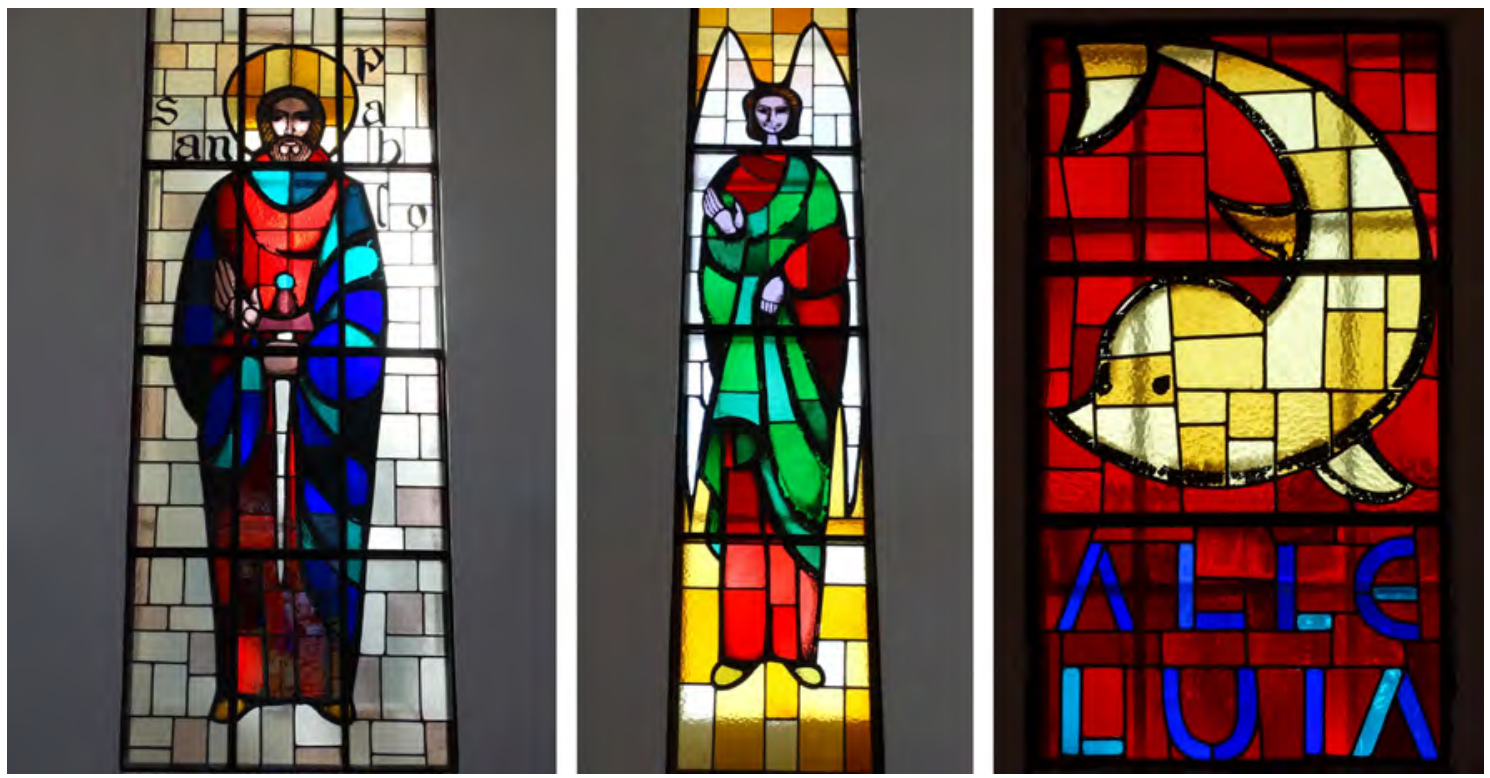

- Fig. 10. Arcadio Blasco. Vidrieras de El Torviscal y Brovales. Fotos de los autores.

cuadrados en cada lado de la nave, incluyendo el coro. También son de cemento, aunque ahora podemos aproximarnos con mayor certeza a su temática. Lo más llamativo es que, junto a un corazón llameante y las Tablas de la Ley, el resto de imágenes alternan plantas y animales. Se adivinan así una maceta con flores, una granada y dos rosas, roja y blanca, en comunión con dos pelícanos, un delfín y un cuadrúpedo que semeja más un caballo que el ortodoxo cordero. Esta pauta sigue en la vidriera del baptisterio, con un grupo de árboles, y en el rosetón del coro, que transita de segmentos rojos, con aves en vuelo, a otros fríos poblados por hojas.

Muy interesantes por su formato $y$ factura resultan las dos grandes vidrieras verticales que iluminan el presbiterio. No son apreciables por los fieles desde la nave, pues se abren en los laterales del altar. La del Evangelio superpone pájaros azules en vuelo ante un intenso fondo rojo, mientras en la Epístola se dibuja con la misma gama un gran crismón, tema mucho menos habitual. Curiosamente está orientado hacia el exterior, lo que nos hace intuir un error en el proceso de montaje.

Los vitrales de la iglesia de Obando (1960) vuelven a la abstracción, o al menos a una figuración tan sintética que no permite vislumbrar elementos reconocibles. Son seis en cada lateral de la nave, separados por marcados arcos fajones y con la peculiaridad de un remate superior curvo. A diferencia de Zurbarán, las líneas internas son curvas y las piezas de vidrio grandes, pero comparte con la citada iglesia la intención de organizar armónicamente el interior. Lo consigue estableciendo una transición cromática gradual entre los colores azules de los pies y el naranja cálido de la cabecera, con eficaces resultados.

También la abstracción preside el rosetón del coro, aunque la rotura de dallas desvirtúa un tanto el profuso cromatismo inicial. Hechos como éste llevaron en los años noventa a proteger los vanos con mallas metálicas.

En un nuevo apartado podemos agrupar las iglesias que utilizan la técnica del emplomado en lugar del hormigón. Blasco se mueve sin problema en ambos frentes, aunque en Extremadura predomine el segundo. La iglesia de El Torviscal (1956) encarna junto a Brovales este proceso, que conlleva además un cambio sustancial de estilo (Fig. 10). No encontramos ahora tanta irregularidad en la disposición curvilínea 
de las dallas. Aquí los fondos se ordenan en retículas, con ligeras variantes de color dentro de cada gama. Sus líneas aparentan ser más finas que las que siluetean los elementos figurativos, pero se debe en realidad a que Arcadio incorpora la pintura al óleo para reforzarlas y darles grosor. También usa el óleo negro para los rasgos del rostro y los textos. Toda una novedad, que en principio resultó eficaz, pero que ha ido sufriendo pérdidas y muestra hoy perfiles desdibujados.

El programa iconográfico es amplio. En las naves se alternan cruces enmarcadas por óvalos de ramas y hojas con la presencia de los cuatro evangelistas. Éstos se muestran sedentes, sin nombres y con un libro o pergamino entre las manos. A los pies de la iglesia, dos motivos apaisados representan un barco y una abigarrada ciudad fortificada cubierta por numerosas cúpulas, renovando los temas.

Pero es que al conjunto hay que añadir la Capilla del Santísimo, un cuerpo anexo con cimborrio octogonal que ha asumido la función de baptisterio, si bien existía para ello otra construcción independiente. Preparando el paso, seis pequeñas vidrieras con temas eucarísticos sorprenden por su composición geométrica. Ya en la propia capilla, las imágenes de San Pedro, San Pablo y San Juan, con sus atributos identificativos, presiden tres de los lados del cubo en actitud frontal y flanqueadas por seis ángeles de factura muy estilizada.

En la pequeña y armónica iglesia de Brovales, al sur de Badajoz, la distribución de las vidrieras emplomadas sigue pautas peculiares. Para iluminar el presbiterio se disponen dos espacios de gran formato, con las figuras completas de San Pedro y San Juan, identificados por sus nombres. Mantienen la combinación cromática primaria, aunque los rectángulos internos presenten diferentes matices y tonalidades, y las carnaciones se muestran en blanco. La articulación es horizontal y regular, solo rota por las curvas sintéticas que configuran las zonas principales del atuendo.

En la nave se consigue un efecto de unidad a lo largo de los 8 rectángulos verticales. El cántico Alleluia en dos líneas azules se recorta ante un rojo intenso, que sirve de sorprendente fondo y ante el que los temas figurativos resaltan en amarillo. La repetición del motivo es muy eficaz en su combinación de colores primarios. Blasco trabaja con símbolos más que con escenas narrativas. Algunos temas resultan curiosos, por su formalidad o su función litúrgica. Así se suceden un delfín, un cordero, tulipanes (flores) y una abeja, y en la nave de la epístola una corona, una estrella de ocho puntas, y un corazón doliente atravesado por una espada. De forma paradójica, se encuentra cegado el vitral más próximo al altar, que representa un candil encendido.

Estos vitrales configuran la parte superior de la nave. Por debajo, completan el conjunto estructuras cruciformes en las que el fondo se torna azul y los motivos amarillos y dorados. Algunos se articulan por parejas y se percibe un diálogo formal o temático entre ambos lados de la nave. Contemplamos así un racimo de uvas frente a espigas doradas; el cáliz con la hostia consagrada opuesto a un recipiente curvo que sostiene una llama aureolada; o una paloma en disposición invertida que armoniza por su disposición con un ancla.

Para concluir esta revisión de las obras de Blasco para el INC, las vidrieras de Tiétar pueden servirnos como resumen, pues muestran un repertorio muy amplio de soluciones $^{25}$. El artista combina en ellas el emplomado y el hormigón. En la nave principal tres enormes y rítmicos vanos horizontales combinan cruces rojas con lo que podrían ser abejas de alas desplegadas. También realiza con plomo (y la misma técnica de refuerzo pictórico vista en El

${ }^{25}$ Realizamos un análisis más extenso en M. CENTELLAS SOLER y M. BAZÁN DE HUERTA, "Arquitectura y Arte...", pp. 59-60. 

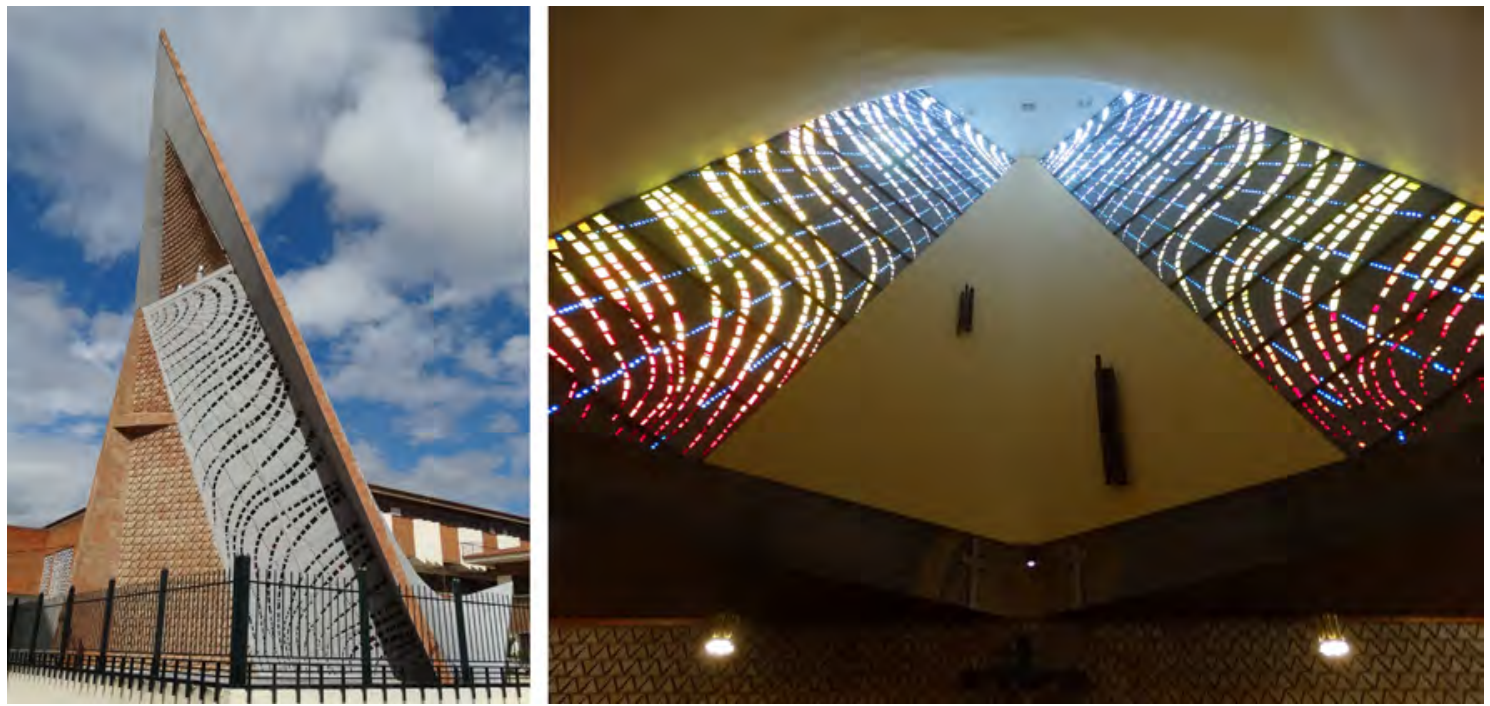

- Fig. 11. Arcadio Blasco. Colegio Menor Santa Teresa. Badajoz. Foto de los autores.

Torviscal) la gran vidriera que ilumina el presbiterio y que reproducimos. Encarna a la Sagrada Familia, protegida por un ángel, en una armónica gama de colores primarios y binarios y ante un fondo blanco. Con criterios equivalentes, algo más sintéticos en los detalles y el rostro, destaca también el ángel músico que da luz al baptisterio, muy estilizado y original en su resolución. También estaba hecho con plomo un gran vitral situado en el coro, pero fue sustituido por otro más moderno en los años noventa, aunque se conserven en el recinto, despiezados, muchos de sus fragmentos vítreos. Una última imagen, a la entrada del templo, vuelve al engarce de cemento y genera con ello una atomización notable. Justifica la advocación de la iglesia a San José Obrero, y muestra a éste ante su mesa de trabajo y junto al Niño Jesús, con modos formales próximos a otras obras del artista, como las realizadas para el templo de El Chaparral (Granada).

Cierra finalmente el capítulo de las vidrieras una obra que se desliga ya de las iniciativas del $\mathrm{INC}^{26}$. Es un encargo privado,

${ }^{26}$ De los estudios sobre Arcadio Blasco se cita en VV. AA., Arcadio Blasco, narrador de objetos..., p. 121. Ver J. M. GONZÁLEZ GONZÁLEZ, Guía de arquitectura de Badajoz 1900-1975, Badajoz, 2011, pp. 193-195. ÍDEM, "Arquitectura religiosa del siglo XX en Badajoz capital procedente del Colegio Menor Santa Teresa en Badajoz, construido entre 1968 y 1969 según proyecto del arquitecto Rafael Andreo Rubio, colaborando en la dirección de las obras Rafael Braquehais García (Fig. 11). Es un interesante edificio, cuyo elemento distintivo es una original capilla con cubierta de hormigón que traza un elegante paraboloide en el espacio, a modo de gran vela. La capilla no tiene acceso exterior, ya que éste se hace desde el propio colegio y bajo el nivel del suelo.

El diseño de Arcadio para las vidrieras del presbiterio crea un efecto similar al despliegue de unas alas de mariposa, en dos superficies inclinadas que convergen en un triángulo superior. Franjas onduladas van ocupando el espacio en un elegante juego de curvas y contracurvas. Lo más sugerente es cómo utiliza la gama cromática, que evoluciona de colores cálidos (rojos, naranjas y amarillos) a fríos (violetas y azules) conforme asciende, creando un efecto de arco iris, muy atractivo visualmente y entre el que se adivinan finos rayos azules por sucesión de puntos.

Sobre el coro se despliega una segunda zona, que al exterior ocupa la base del pa-

(Extremadura)", en Actas del Congreso Internacional de Arquitectura Religiosa contemporánea, La Coruña, vol. 2, 2011, pp. 180-181. 


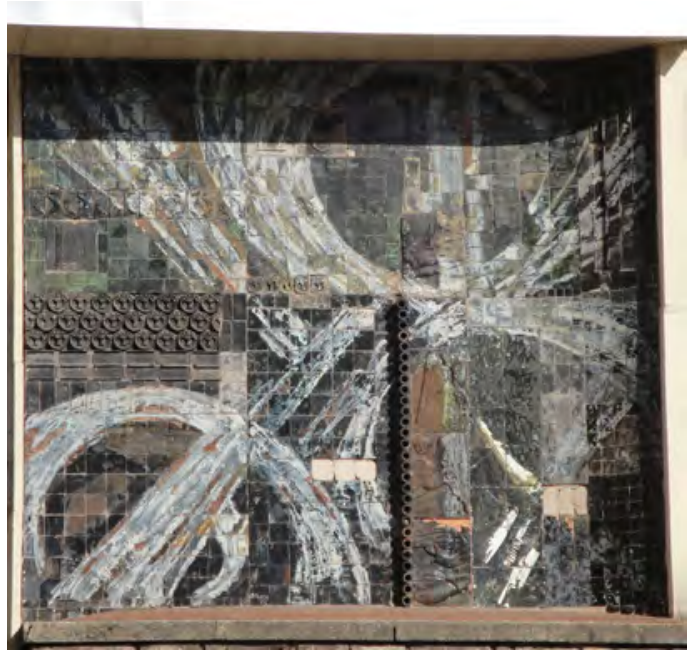

- Fig. 12. Arcadio Blasco. Mural del edificio de la Agencia Tributaria. Cáceres. Foto de los autores.

raboloide. Dentro, sobre sendas franjas con mosaicos abstractos, y a partir de un pilar central, se abren las dos estrechas superficies triangulares de hormigón que acogen los vitrales. Éstos trazan líneas concéntricas que sugieren un corazón y se van abriendo, combinando colores entre una fina estructura radial de rayos azules.

En la documentación que conserva el colegio hay correspondencia que revela desavenencias en el proceso de ejecución ${ }^{27}$. Al parecer el diseño original de Arcadio fue modificado a instancias del arquitecto. Se encomendó para ello la realización a una empresa no suficientemente especializada. Ante las filtraciones de agua que se produjeron, el colegio se niega a satisfacer los honorarios al artista, pero éste justifica que las consecuencias no son culpa suya y en todo caso los responsables serían el arquitecto o la empresa instaladora. Desconocemos cómo se resolvió finalmente el problema, pero en la actualidad el conjunto se conserva en muy buen estado.

Un último trabajo, esta vez en la capital cacereña, se centra en el ámbito de la arquitectura civil. Es la intervención de Arcadio

${ }^{27}$ Archivo del Colegio Menor Santa Teresa de Badajoz. Las cartas de Blasco llevan el logo de su empresa "Artesanías Olarca" de Majadahonda.
Blasco en el edificio de la Delegación de Hacienda, hoy Agencia Tributaria, en la calle Sánchez Herrero (Fig. 12). El interior alberga dos grandes e interesantes vidrieras abstractas de cemento que completan así el panorama de su producción para Extremadura. Son de carácter abstracto y combinan formas rectilíneas y curvas en una gama dominante de blancos, azules y rojos.

Pero resulta más novedoso el gran mural cerámico que realiza para la portada del edificio, firmado y fechado en 1964. Es una propuesta sorprendente por la profusión de elementos y su carácter aglutinador. En el ámbito civil es una obra única, pero presenta paralelismos con otras propuestas religiosas del autor ${ }^{28}$. Sobre una superficie que se curva en un lateral, dispone azulejos de diferentes tamaños y también piezas de terracota modeladas en relieve. Algunas son reaprovechadas, pues las encontramos en otras obras y difícilmente se explica, si no, la presencia de un tetramorfos con los símbolos de los evangelistas, fragmentados y casi camuflados bajo las manchas pictóricas. Letras mayúsculas, como la $\mathrm{L}$ y la $\mathrm{O}$, aparecen también de forma un tanto aleatoria. En registros más ordenados introduce las franjas de elementos vegetales, frutas y árboles, obtenidos por molde y en disposición seriada, más una línea vertical de cilindros transversales al muro. Estos elementos, muy oscuros, articulan y dotan de volumen a una superficie inusual, a la que por contraste se aplican barnices claros superpuestos a la trama. Y lo hacen con un lenguaje plástico informalista, propio de las vanguardias de la época, muy gestual, trazando con manchas grandes círculos y diagonales que imprimen al resulta-

${ }^{28}$ Es el caso de la iglesia de Maruanas, en El Carpio, Córdoba (hacia 1962), en cuyo exterior monocromo combina elementos geométricos con otros vegetales, aves y cabezas de ángeles. Pero aún más llamativo es el despliegue colorista del interior. En los murales del presbiterio y el frente de altar encontramos la alternancia de zonas abstractas con moldes cerámicos en los que proliferan pájaros volando, árboles y ángeles de nuevo, configurando una suerte de patchwork cerámico muy singular, cuyo modelo Blasco había utilizado también en el altar de la iglesia de Cañada de Agra (Albacete). 
do un gran dinamismo ${ }^{29}$. En definitiva, una obra arriesgada que, aunque con pequeñas pérdidas de azulejos, sigue presidiendo un conocido y visible enclave de la ciudad de Cáceres.

Hasta aquí el recorrido, que ha permitido dar a conocer una faceta poco conocida en la trayectoria de Arcadio Blasco, y que conviene también rescatar a nivel nacional. Su apuesta por la vanguardia y la abstracción se afianzará en los años siguientes pero aporta ya en estas fechas rasgos de modernidad. Blasco resolvió

${ }^{29}$ Sigue parámetros similares a su "Composición desde la espiral", reproducida en M. GARCÍA-VIÑÓ, Arcadio Blasco..., p. 34. estas obras con solvencia y se revela un artista versátil, capaz de introducir ricas variantes en las vidrieras (figurativas o abstractas) o incorporar técnicas como el pirograbado, propio de sus trabajos para esta zona. Estas creaciones permiten comprobar que, más allá de su posicionamiento ideológico, el artista supo adaptarse a los diferentes encargos y que en estas fechas el peso de la temática religiosa, aunque partiera de un organismo oficial, seguía teniendo gran protagonismo en las artes plásticas españolas ${ }^{30}$.
${ }^{30}$ Ver, entre otros, M. T. GONZÁLEZ VICARIO, Aproximación a la escultura religiosa contemporánea en $M a-$ drid, Madrid, 1987; o C. MONTOYA ALONSO, La pintura mural religiosa en el Madrid del siglo XX, Tesis Doctoral defendida en la Universidad Complutense de Madrid, 2005. 